\title{
Report of Symposium of the Obstetric Group of S.A. Society of Physiotherapy
}

\section{PHYSIOTHERAPY and the PELVIS*}

\author{
PHILLIP V. TOBIAS
}

F.R.S.(S.Af.), F.L.S.(Lond.), D.Sc., Ph.D., M.B.B.Ch. Honorary Vice-President,

South African Society of Physiotherapy

This Symposium and First Annual General Meeting of the South African Society of Physiotherapy Obstetric Group represent an important step forward in the life and work of your Society.

\footnotetext{
"Brief address at the Official Luncheon marking the First Symposium of the First Specialized Group the Obstetrics Group - of the South African Society of Physiotherapy, 23rd March 1974.
}

In the absence of your President, Professor B. Bromilow-Downing, let me express my praise and congratulations to the Society on the establishment of this, the first of its Specialised Groups.

The inception of the Obstetric Group a year ago was another landmark - and this meeting is another milestone - in the advance of Physiotherapy in Southern Africa. In fact, significant developments in Physiotherapy are occurring at such a tempo these days that one scarcely has time to catch one's breath. Only last year, the Professorial Board for Physiotherapy came into being and one found oneself congratulating Professor Jean Blair on her election as its first Chairman. Only a year or two have passed since the Witwatersrand University inaugurated a new degree, the Master of Science in Physiotherapy, and already our first candidates are completing their dissertations. I wonder how long it will be before we find ourselves considering the establishment of a South African College of Physiotherapy! 
.I should be failing in my duty if I were not to convey my warm felicitations to Mrs. Audrey McFarlane and her Committee on conceiving and giving birth to the Obstetric Association - appropriately a happy birthday. I should especially like to express appreciation to Miss Rosemary Harte on convening what has undoubtedly been a most successful Symposium. I know I speak for all of you when I extend thanks and gratitude to the speakers - some of whom have come all the way from Pretoria and Cape Town, as well as some of our local luminaries, for their contributions last evening; and to Professor Jack Allan for conducting the Lecture/Demonstration this morning.

- Obstetrics - what a crucial area with which to begin your specialised groups; for everything begins with it. And, after all, as a great medical man once said, is not this pelvis the triumphal arch through which passes every youthful candidate for immortality?

This pelvic triumphal arch is one of the supreme products of evolutionary genius: for it has attained its human form and function while overcoming two or three major and sometimes conflicting challenges. One was the trend in ancient times towards an increase in the brain size of the newborn baby; with this went the need for a concomitant enlargement of the birth-canal; and the third was the attainment by our ancestors of uprightness.

The way in which these apparently irreconcilable biological goals were achieved without the pelvic mechanism falling into a heap of ruins, or our species giving up the seemingly unequal struggle and becoming extinct, is one of the great sagas of human development.

En dis snaaks dat, nieteenstaande die feit dat hierdie ewolusie van vernaamste belang is, navorsing in hierdie area ' $n$ baie jong en nuwe ontwikkeling is. Eenvoudig is die kwessie soos volg: Hoe kon dit gebeur het dat die fetus 'n drievoudige vergroting van sy brein versoen met die vereistes van 'n normale geboorte; en terselftertyd versoen met die veranderings in die bekkenbeen. sy gewrigte en sy spiere - wat die bereik van opregtheid vergesel het?

The mind boggles at the thought that we ever survived this threefold challenge of the bigger-brained newborn baby, demanding a more capacious birthcanal; the maintenance, nevertheless, of normal parturition; and the major pelvic readjustments that accompanied the attainment of the upright stance and bipedal gait.

Yet survive we did; and only by the development of a superb mechanism whose nuances have been occupying your attention last evening and this morning.

Yet even the most perfect of Nature's mechanis needs the guiding hand of the therapeutic team from time to time. So it is fitting that your Society has organised this Symposium on the role of the physiotherapist in helping to ease those musculo-ligamentous problems which our most spectacular and all-too-recent evolutionary revolution has left in its wake. 